\title{
EL IMPACTO DE LA NUEVA LEY CUBANA DE SÍMBOLOS NACIONALES EN LOS DERECHOS DE PROPIEDAD INTELECTUAL*
}

\author{
The impact of the new National Symbols Cuban Law on \\ intellectual property rights
}

O impacto da nova lei cubana de símbolos nacionais sobre os direitos de propriedade intelectual

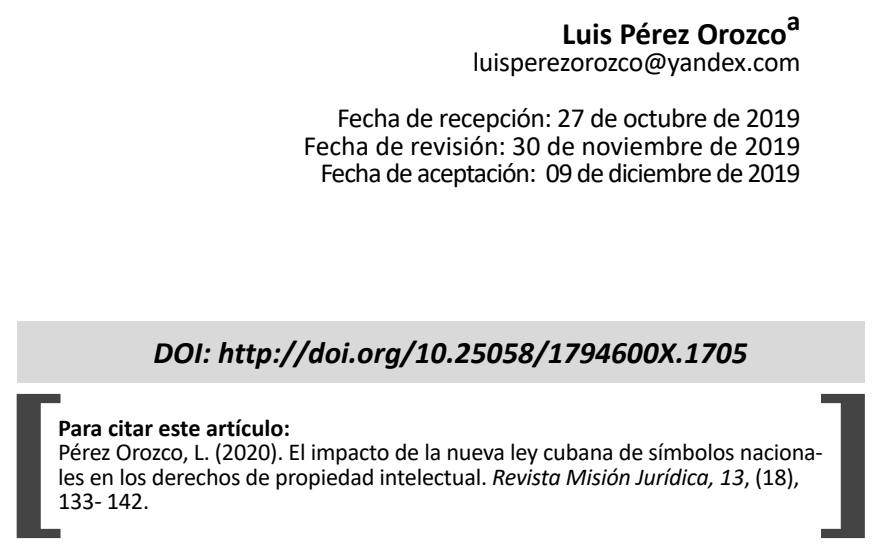

\section{RESUMEN}

El objeto del presente trabajo es analizar las implicaciones de la Ley de Símbolos Nacionales de 2019 para el sistema de la propiedad intelectual cubana. El estudio se realizó a partir de considerar la correspondencia de la ley con las normas jurídicas vigentes sobre propiedad intelectual. Se tomó este enfoque debido a la falta de investigaciones al respecto, tanto en el ámbito nacional como foráneo. Como resultado se evidenció que la situación de los símbolos nacionales es diferente a la de los atributos. Para los primeros existen limitaciones en la propiedad intelectual, sin embargo, los segundos gozan de facilidades debido a la inexistencia de disposiciones jurídicas. Se concluye que la nueva ley refuerza la protección a los símbolos nacionales en sede de la propiedad intelectual. Su aplicación y control son procesos complejos motivados por la masificación de los símbolos en

\footnotetext{
* Artículo de reflexión presentado en el XII Taller Nacional Patria, Símbolos e Identidad llevado a cabo en la Universidad de Matanzas, Cuba, en 2019. Además, el autor desea agradecer a los pares revisores académicos por las sugerencias aportadas y a la Dr.C. Arletys Varela Mayor, Profesora de Derecho de Autor de la Universidad de Matanzas, por su contribución a la calidad de la investigación.

a. Licenciado en Derecho. Asesor Jurídico y Profesor de Derecho Constitucional, Universidad de Matanzas, Cuba. ORCID: https:// orcid.org/0000-0002-4289-0051
} 
la práctica comercial, a pesar de las regulaciones legales. Se debe potenciar la formación de valores y la cultura jurídica en torno al respeto a los símbolos nacionales.

\section{PALABRAS CLAVES}

Propiedad intelectual, símbolo nacional, ordenamiento jurídico.

\section{ABSTRACT}

The purpose of this paper is to analyze the implications of the National Symbols Law of 2019 for the Cuban intellectual property system. The study was conducted from the correspondence of the Law with the legal regulations currently in force on Intellectual Property. Itis a new and original approach to the subject because there is no national or foreign scientific research. As a result, it became evident that the situation of national symbols is different from that of attributes. National symbols are restricted on Intellectual Property, however, it has been removed control from its attributes. It is a concluded that the new National Symbols Law strengthens the protection on Intellectual Property. The implementation and control of this Law is a complicated process that gives everyone access to national symbols in domestic trade, despite legal regulations. The formation of values and legal culture regarding national symbols must be promoted.

\section{KEY WORDS}

Intellectual Property; national symbol; legal system.

\section{RESUMO}

O objetivo deste artigo é analisar as implicações da lei nacional de símbolos de 2019 para o sistema de propriedade intelectual cubano. 0 estudo foi realizado com base na correspondência da lei com as normas legais vigentes sobre propriedade intelectual. Essa abordagem foi adotada devido à falta de pesquisas nesse sentido, tanto nacional quanto internacionalmente. Como resultado, ficou evidente que a situação dos símbolos nacionais é diferente da situação dos atributos. Para os primeiros, existem limitações à propriedade intelectual; no entanto, os últimos desfrutam de instalações devido à ausência de disposições legais. Conclui-se que a nova lei reforça a proteção de símbolos nacionais baseados em propriedade intelectual. Sua aplicação e controle são processos complexos motivados pela massificação de símbolos na prática comercial, apesar dos regulamentos legais. A formação de valores e a cultura jurídica em torno do respeito aos símbolos nacionais devem ser promovidas.

\section{PALAVRAS-CHAVES}

Propiedad intelectual; símbolo nacional; ordenamiento jurídico; ley cubana de símbolos nacionales.

"No se debe menospreciar el valor cultural, político, histórico y moral de los símbolos, ni sucumbir al pensamiento pragmático, al acomodamiento y la resignación, que llevan a ignorar "detallitos" como la importancia de que, quien esté en Cuba, sienta que se halla en este país, no en otro, y lo rodea la cultura cubana, no Luis Toledo Sande.

\section{INTRODUCCIÓN}

El análisis de los símbolos nacionales $\mathrm{u}$ oficiales de un país puede hacerse principalmente desde tres aristas: sociocultural, histórica y jurídica. De ahí que Troncoso considera que:

La simbología de una nación está contenida de forma apriorística en la psicología colectiva y forma parte de nosotros nada más nacer. En verdad los símbolos no nos pertenecen como ciudadanos, somos nosotros los que pertenecemos a ellos a partir del descubrimiento de lo simbólico, el hombre se da cuenta de que existen realidades poderosas y significativas, y por tanto, realidades necesarias frente a la contingencia de la propia existencia. (...) Además, los símbolos son multivalentes, siendo capaces de expresar a la vez distintas significaciones al mismo tiempo (2018: 33).

La tutela que el Derecho le otorga a los símbolos se circunscribe al texto constitucional y sus leyes complementarias, el orden administrativo mediante contravenciones, el sistema penal y las normas de propiedad intelectual. En esta última disciplina jurídica se les protege fundamentalmente a través de limitaciones o prohibiciones. En Cuba, una nueva 
ley sobre símbolos nacionales entra en vigor ${ }^{1} y$ en ella se encuentran mandatos referidos a la propiedad intelectual. Sobre esta temática en específico no abundan los estudios doctrinales y los existentes son enfocados desde el Derecho penal.

Con base en lo planteado se define como problema científico de esta investigación determinar si la nueva Ley de Símbolos Nacionales en Cuba refuerza la disparidad en las regulaciones jurídicas sobre los símbolos y atributos nacionales e incide en la protección adecuada de los derechos de propiedad intelectual. Por tanto, se traza como objetivo general analizar las implicaciones de la nueva ley cubana de símbolos nacionales para la propiedad intelectual.

Se utilizaron como métodos el deductivoinductivo que permitió ir de lo general (el examen de disposiciones legales y resoluciones jurisdiccionales foráneas y nacionales) a lo particular (artículos de esas disposiciones y párrafos específicos). Además, cuando se aplica una norma jurídica a la solución de un caso se hizo uso de este. También resultó necesario el método análisis-síntesis para determinar las características más acuciantes del ordenamiento jurídico sobre los símbolos nacionales como objeto investigado, al implicar una abstracción mediante la cual se segmentó en aquellas cualidades que lo representen. El método de análisis histórico contribuyó a la comprensión total del objeto de estudio y brindó la visión de la transición en el tiempo de la norma y la jurisprudencia. Fueron consultadas resoluciones judiciales foráneas, pues en el territorio nacional no han trascendido casos similares. Las mismas se asumen como referentes para sustentar algunos de los criterios emitidos por el autor, sin que se trate de un análisis de Derecho comparado en sentido estricto.

\section{Regulación jurídica de los símbolos nacionales cubanos}

La selección de los símbolos nacionales $\mathrm{u}$ oficiales es una práctica histórica situada en el surgimiento del Estado-nación. Ellos representan los valores más relevantes, la historia de cada país a la vez que lo identifican del resto de los Estados.

1. Ley No. 128 "Ley de los Símbolos Nacionales de la República de Cuba", de 13 de julio de 2019. Gaceta Oficial No. 71 Ordinaria de 19 de septiembre de 2019.
De esta breve referencia es posible entender que el significado que subyace a los símbolos patrios comprende la idea del origen común de la Nación, marcada por sus vicisitudes históricas. La exaltación de este origen (...) compromete a todos en la empresa de impedir que los valores fundantes de la patria desaparezcan (...) En fin, el mensaje de dicha simbología realza la gesta de un pueblo que luchó por su independencia, logró la libertad y busca la prosperidad de sus hijos en el mismo territorio de sus ancestros (Corte Constitucional de Colombia citada por García, 2013: 220) ${ }^{2}$

También con acierto sintetiza González Alcantud que:

(...) hemos de buscar las explicaciones más lógicas a la existencia de la nación a símbolos de identificación colectiva como son las banderas y los himnos nacionales, tanto en el contexto patriótico e internacional como en sí mismos y en su fuerza semántica para generar emociones (González, 2003: 134).

La actual Constitución de la República de Cuba, en su artículo 2, refrenda como símbolos nacionales a la bandera de la estrella solitaria, el Himno de Bayamo y el escudo de la palma real. Además, agrega que la ley define las características identificativas de los mismos, su uso y conservación. Por su parte el artículo 90, inciso c), establece como deber de los ciudadanos respetar y proteger los símbolos patrios ${ }^{3}$. La utilización

2. Así el Tribunal Supremo de España, Sala de lo Contencioso, en su Recurso No. 4280, de 4 de marzo de 2013, Juez Ponente José Díaz Delgado, expresó en su Fundamento Octavo: "No puede desconocerse que la materia sensible del símbolo (...) trasciende a sí misma para adquirir una relevante función significativa. Enriquecido con el transcurso del tiempo, el símbolo... acumula toda la carga histórica de una comunidad todo un conjunto de significaciones que ejercen una función integradora y promueven una respuesta socioemocional, contribuyendo a la formación y mantenimiento de la conciencia comunitaria, y, en cuanto expresión externa de la peculiaridad de esa Comunidad adquiere una cierta autonomía respecto de las significaciones simbolizadas, con las que es identificada; de aquí la protección dispensada a los símbolos... por los ordenamientos jurídicos (...)". El Tribunal de Justicia de la Unión Europea, en la Sentencia No. C-202/08, de 12 de mayo de 2009, como parte de las Conclusiones del Abogado General pronunció que: "(...) los lazos entre los emblemas nacionales y los súbditos de un mismo Estado hunden sus raíces en la historia, la cultura, las tradiciones, las tierras, la trayectoria internacional e incluso la idiosincrasia típica de un pueblo. En general, esos emblemas son símbolos de una nación de los que sus portadores se sienten, en mayor o menor medida, orgullosos".

3. El precepto constitucional in comento también rige para las personas que deseen adquirir la ciudadanía cubana. En el 
del término "patrios" en lugar de "nacionales" como lo hace el artículo 2, permite incluir a los llamados atributos como son el tocororo, la flor de la mariposa y la palma real. No obstante, una interpretación en sentido amplio del artículo admitiría otros elementos representativos como el baile y deporte nacionales.

Las normas anteriormente rectoras del uso de estos símbolos se ubican en la Ley No. 42 "De los símbolos nacionales" de 27 de diciembre de 1983, el Decreto No. 143 de 13 de abril de 1988 y el Decreto No. 141 de 25 de marzo de 1988. Los atributos no cuentan con una regulación legal específica y su destino lo han marcado la política estatal y las costumbres sociales (Amaro, 2014: $37,45)^{4}$.

Desde la aprobación de estas normas y hasta la actualidad diversos acontecimientos a lo interno y externo de Cuba han transformado la visión ciudadana de la realidad. El país no escapa del fenómeno de la globalización que implica el aumento del consumo de bienes y servicios extranjeros con sus respectivos diseños y marcas y la guerra cultural mundial donde los símbolos son una de las principales armas de ataque. Así, hoy día, algunas personas utilizan los símbolos nacionales de otros Estados en su vestuario

examen que a tales efectos se realiza se comprueba, entre varios requisitos el conocimiento de los símbolos nacionales. Véase Decreto-Ley No. 352 "Sobre la adquisición de la ciudadanía cubana por nacimiento de los nacidos en el extranjero de padre o madre cubanos", de 30 de diciembre de 2017, Disposición Especial Tercera. Gaceta Oficial No. 63 Extraordinaria, de 30 de diciembre de 2017.

4. La palma real es reconocida expresamente como símbolo nacional en la Ley No. 85 "Ley Forestal", de 21 de julio de 2018, Gaceta Oficial No. 46 de 31 de agosto de 1998. En función de protegerla se pronuncian la Resolución No. 330 Reglamento de la Ley Forestal, de 7 de septiembre de 1999, del Ministerio de Agricultura, en Gaceta Oficial No. 57 Ordinaria de 10 de septiembre de 1999 y el Decreto No. 268 "Contravenciones de las regulaciones forestales", de 8 de septiembre de 1999 en Gaceta Oficial No. 58 Ordinaria de 17 de septiembre de 1999. Además, se hace referencia a ella en la Resolución No. 169 que aprueba la lista oficial de variedades vegetales comerciales, de 17 de marzo de 2017, del Ministerio de la Agricultura en Gaceta Oficial No. 18 Ordinaria de 16 de junio de 2017. El Ministerio de la Construcción la menciona en la Resolución No. 200 sobre la Regulación de la Construcción RC 1081.2018 relativa a los requisitos de proyectos y de calidad de los materiales a emplear en las nuevas inversiones de carácter turístico, recreativo, agrícola y de viviendas de la Gaceta Oficial No. 49 Ordinaria de 13 de diciembre de 2018. Por otra parte, sin llegar a nombrarlo como símbolo, el tocororo se enlista en la Resolución No. 160 "Regulaciones para el control y la protección de especies de especial significación para la diversidad biológica del país”, de 28 de junio de 2011 del Ministerio de Ciencia, Tecnología y Medio Ambiente, según Gaceta Oficial No. 026 Ordinaria de 4 de agosto de 2011. o adquieren productos comerciales con esas representaciones. Sin embargo, más preocupante es el uso que los cubanos les dan a los suyos, a pesar de las restricciones legales existentes.

El recibimiento al crucero Adonia perteneciente a la empresa Carnival Corporation, por bailarinas que portaban la bandera en su vestimenta en el puerto de La Habana, en 2016, provocó reacciones más allá de las fronteras capitalinas. También fue notoria en esta provincia la tienda particular, ubicada en el bulevar de Obispo con la oferta de delantales para cocinar recreados con la enseña. La revista Bohemia No. 25 de 7 de diciembre de 2018 bajo el título "Una bandera cubana en el Olimpo" publicó en su portada una foto donde la enseña nacional está al revés. La figura del Che estampada sobre la bandera es observada en actividades políticas y patrióticas, a pesar de la prohibición legal de realizar diseños así. Algunos automóviles, fundamentalmente del sector privado, colocan la bandera en cualquier lugar del vehículo, acompañándola en ocasiones con textos ajenos al patriotismo. Las opiniones estuvieron divididas cuando Alexander Abreu, cantante principal de la agrupación Havana d' Primera, en la obra musical "Me dicen Cuba" evocó con su trompeta acordes del Himno de Bayamo, una pieza que solemnizó las batallas por la libertad de la isla, expresión artística donde se entrecruzan el sentimiento de amor patrio y la decisión de combate (Rodríguez, et al., 2018). Felizmente, el escudo es muy pocas veces visto en contextos distintos a los establecidos legalmente.

La situación ameritó en 2016 una proclama del Historiador de La Habana, Eusebio Leal Spengler:

Con profunda pena hemos venido observando que la enseña nacional, la gloriosa bandera de la estrella solitaria que no ha sido jamás mercenaria, está a la venta entre otros productos de la artesanía como si se tratara de una de ellas o de un objeto común (...) hago un patriótico y ardoroso llamamiento a nuestros conciudadanos y al menos aquí en el Centro Histórico de La Habana, Patrimonio Mundial, se apeguen las costumbres públicas a las leyes vigentes y NO [sic] se pisotee NI [sic] se ponga precio (Leal, 2016, s.p.).

En 2019 tras la aprobación del nuevo texto constitucional y con la premisa de atemperar las normas jurídicas a la realidad del país, se hizo 
pública la convocatoria para conocer la opinión de la ciudadanía y los especialistas con vistas a una nueva ley de símbolos nacionales. Es evidente la necesidad de actualizar la normativa legal vigente sobre la materia, así como puntualizar y precisar sus contenidos; partiendo del principio de alcanzar una norma que establezca un uso más flexible de los símbolos nacionales para apreciar, dentro de un estado de orden y respeto a la legislación, mayor presencia de los mismos en la sociedad, facilitando el conocimiento y acatamiento consciente de esta ley.

La ley tiene como objetivo solucionar la problemática apreciada en la sociedad cubana en cuanto a la antinomia entre lo estipulado en la vigente Ley de los Símbolos Nacionales, su reglamento y el uso que hacen e interesan los ciudadanos dar a los mismos. De esta forma permitirá incrementar los sentimientos patrios de respeto y veneración a los símbolos nacionales como expresión de los emblemas más universales de la nación, representativos de toda su historia. Si bien los atributos también son expresivos de las luchas del pueblo por su libertad, la ley establece como tal a los reconocidos en el artículo 2 de la Carta Magna, por lo que dicha tríada constituirá los que representen al país en el plano nacional y foráneo.

La propia ley se presenta como reglamentaria, y en ese carácter radica en su contenido, por tanto, no se refiere a la relación jerárquica con las demás leyes. Como deriva de un proceso legislativo y no emana de la función ejecutiva, la norma es autosuficiente y no requiere un reglamento.

Son varias las novedades de la nueva ley: sobre la bandera se consignan los elementos contentivos y su significado, lo que permite interpretar mejor el mensaje patriótico latente; se sustituyen los tejidos para confeccionarla y se incorpora la posibilidad de elaborarla con otros para abaratar su elaboración y facilitar su adquisición; se incorpora su uso por personas naturales en actos públicos, domicilios, centros laborales; se eliminan algunas prohibiciones; se abordan las características y empleos del Himno, el Escudo y el Sello de la República, así como los honores que se rinden a los dos primeros. En fin, se armoniza la legislación sobre el tema con la realidad social, se satisface un justo reclamo de los ciudadanos y se fortalece la legalidad.

\section{La expresión de los símbolos nacionales en la propiedad intelectual}

La propiedad intelectual se refiere a toda creación de la mente humana y protege los intereses de los creadores al ofrecerles prerrogativas en relación con sus productos. Esta disciplina del Derecho está relacionada con las creaciones de la mente: los inventos, las obras literarias y artísticas, los símbolos, los nombres, las imágenes y los dibujos y modelos utilizados en el comercio. Para su estudio se divide en Derecho de autor (obras científicas, artísticas, literarias y educacionales de carácter original, que se hayan hecho o puedan hacerse de conocimiento público por cualquier medio lícito, sin importar sus formas de expresión, contenido, valor o destino) y propiedad industrial (creaciones intelectuales de carácter técnico y comercial).

Si bien el art. 62 de la Constitución reconoce a las personas los derechos derivados de la creación intelectual, también dispone que los mismos se ejercen por los creadores y titulares en correspondencia con la ley, en función de las políticas públicas. Por tanto, los ciudadanos no están exentos del cumplimiento de todas las normas jurídicas complementarias a la Carta Magna. Nadie puede alegar el desacato a la ley amparándose en un derecho de rango constitucional.

En la Ley de Símbolos Nacionales tanto la bandera como el escudo están expresamente prohibidos en anuncios, marcas, símbolos o propagandas comerciales ${ }^{5}$. Se prevé la posibilidad de que los símbolos nacionales se utilicen en prendas de vestir, objetos, obras de arte y escritos, siempre con el mayor respeto y decoro; corresponde considerar el contexto de su utilización y el objeto donde están representados,

5. Esta es una prohibición característica de la mayoría de los Estados, pero existen excepciones a esa regla. A pesar de la polémica, algunas marcas apuestan por las banderas para sus diseños y sus logos. Vespa es una de las pioneras en esta estrategia de abarcar mercado y clientes con prendas personalizadas con enseñas de diversos países. En Italia, Ferrari incluye en gran cantidad de sus diseños a la bandera. En el caso de Tommy Hilfiger no es estrictamente el estandarte norteamericano, pero sí lleva sus colores y varias de sus vestimentas dibujan la bandera de barras y estrellas. La francesa Lacoste no incluye pabellón alguno en su logo, sin embargo, ha promocionado versiones donde su famoso caimán se envuelve en diferentes banderas nacionales. Swissarmy, de Suiza, tiene un catálogo de ropa complementos, navajas y joyas con la cruz blanca sobre fondo blanco. Napapijri es un claro ejemplo de cuando una bandera se convierte en logo. En este caso es la de Noruega y representa a la marca de abrigos de nieve por excelencia. 
y solo pueden usarse como medio de publicidad cuando trasladen mensajes promotores de valores patrios en las personas. De este modo, la norma establece con rango de ley algunas pautas rectoras para los procesos creativos, resultados, comercialización y correspondiente protección por el Derecho.

La sustracción de las prohibiciones legales sobre el uso del Himno contrasta con los impedimentos de los otros símbolos. Al respecto, ciertas pautas debieran ser establecidas en aras de garantizar su enaltecimiento. Como este símbolo nacional es de dominio público, sobre él no recaen derechos de autor y por tanto nadie puede adjudicarse como propia su autoría o algún arreglo hecho a su melodía. Por ejemplo, en la versión de un fragmento del Himno en la canción "Me dicen Cuba", su autor está imposibilitado de registrar dicho segmento como obra original. No obstante, le permite al intérprete publicitarse en todo el país y trascender más allá de sus consumidores habituales. La musicalización en salsa del Himno es cuestionable y, a criterio del investigador de este trabajo, un acto irrespetuoso con un símbolo representativo de las luchas por la independencia. ${ }^{6}$ Sin embargo, el Estado consiente y promueve la difusión de la canción, lo que se demuestra en la recurrente trasmisión de la obra por los medios de comunicación y el otorgamiento de una réplica de la letra del Himno a su intérprete a principios de 2019.

En el ámbito de la propiedad industrial, el Decreto-Ley 203 "De marcas y otros signos distintivos" otorga una triple protección a los símbolos nacionales y prohíbe el registro de marcas que incluyan una reproducción o imitación, total o parcial de un escudo, bandera $\mathrm{u}$ otro emblema, sigla o denominación de cualquier Estado u organización internacional, de monedas o papel moneda, sin autorización expresa de esos sujetos del Derecho Internacional Público. Tampoco pueden incluir una reproducción o imitación, total o parcial, de un signo oficial o de un signo o punzón de control y garantía del Estado cubano o de un Estado extranjero, o de una entidad pública nacional o extranjera, provincial

6. Para una comprensión integral del significado del Himno Nacional de un país puede consultarse Alegre Martínez, Miguel Ángel. "Los símbolos políticos: su entidad cultural, representativa e integradora". Derecho Constitucional (2011). o municipal, sin autorización expresa de la autoridad competente.

Procede señalar que los emblemas de Estado y de organizaciones internacionales intergubernamentales están protegidos no sólo contra el registro y la utilización de marcas idénticas o que los incluyan, sino también contra la utilización en estas marcas de toda imitación de los emblemas desde el punto de vista heráldico (Tribunal de Justicia de la Unión Europea, 2004, s.p.).

El decreto-ley también impide el registro marcario de signos contrarios a la ley, a la moral o el orden público. ${ }^{7}$

De forma muy similar al derecho marcario sucede con la normativa de denominaciones de origen e indicaciones de procedencia ${ }^{8}$. Sería denegada la licencia con la pretensión de designar la calidad de un producto o servicio aludiendo que los mismos provienen de la zona campestre representada en el escudo.

En cuanto a los dibujos y modelos industriales tampoco es admisible patentar productos con los diseños de los símbolos nacionales. A pesar de que la ley no lo prohíbe expresamente, el DecretoLey No. 290, regulación específica de esta materia, sí lo hace al impedir el registro de dibujo o modelo sin deferir en grado significativo de diseños conocidos o de combinaciones de características conocidas de diseños; o sea contrario a los intereses sociales, al orden público o a la moral. ${ }^{9}$ Ergo, la alteración sufrida en el escudo no puede quedar con un mero acto de diseño creativo, pues la ley reguladora de los símbolos es de orden público y no está sujeta a la voluntad particular (Garza, 2006: 187).

Muy estrechamente vinculado con la propiedad industrial se descubre el fenómeno de la publicidad. Como forma de comunicación comercial de los signos distintivos intenta

7. Decreto-Ley No. 203 "De las marcas y otros signos distintivos", de 24 de diciembre de 1999, Artículo 16.1 incisos h), i), k) y l). Gaceta Oficial No. 3 Extraordinaria de 2 de mayo de 2000.

8. Decreto-Ley No. 228 "De las indicaciones geográficas", de 20 de febrero de 2002, Artículo 45.2 incisos a), b) y c). Gaceta Oficial No. 11 Ordinaria de 22 de febrero de 2002.

9. Decreto-Ley No. 290 "De las invenciones y dibujos y modelos industriales", de 20 de noviembre de 2011, Artículo 92 incisos f) y e). Gaceta Oficial No. 002 de 1 de enero de 2012. 
incrementar el consumo de un producto o servicio a través de los medios de comunicación y de técnicas de propaganda.

Para el territorio nacional está dispuesto jurídicamente que la publicidad, en su función de orientación para el consumo, no debe utilizar los símbolos nacionales, ni imágenes de próceres y dirigentes de la Revolución, a no ser los debidamente autorizados por los órganos competentes. Además, debe considerar las indicaciones existentes para la venta de artículos promocionales considerados Imagen Cuba, donde se empleen el escudo y la bandera, que se correspondan con las disposiciones normativas. Estos objetos siempre serán comercializados como suvenir y no deben constituir artículos de uso, o sea, se pueden utilizar los símbolos impresos en los diferentes soportes, pero nunca deben quedar como soportes publicitarios. ${ }^{10}$ Aunque dicha norma no está derogada, su contenido es letra muerta. Los productos comerciales con el diseño de la bandera, fundamentalmente, desbordan los marcos que pretendió establecer la Resolución en su momento. Por ejemplo, Artex S. A. actualmente comercializa diferentes bienes con impresiones de los símbolos, y ¿acaso no es esa una forma de soporte publicitario implícito para la empresa en cuestión? El debate se ha incrementado con la incorporación del trabajo por cuenta propia a ese concierto de mercantilización. La polémica es mayor si se tiene en cuenta la publicidad hecha con símbolos nacionales en el ciberespacio, un terreno difícil de legislar.

La inexistencia de un estatus legal para los atributos determina la permisividad de su uso y así se expresa en las diversas alusiones a los mismos en las modalidades de la propiedad Industrial y su publicidad comercial. El tocororo fue la mascota de los Juegos Panamericanos de 1991, representa a un restaurante del mismo nombre en La Habana, un servicio de comunicaciones del extranjero hacia Cuba y un conjunto de establecimientos del Grupo de Tiendas Panamericana. La palma real identifica a la cerveza Cristal y denomina a un Hotel en Varadero, el mayor polo turístico del país. Mientras, la flor de la mariposa figura en

10. Resolución No. 201 del Ministerio de Comercio Interior, Aprueba Lineamientos Generales para el Programa de Comunicación Comercial de las Entidades que Participan en el Mercado Interno en Divisas, de 2 de junio de 2003, Apartados 1.5 y 1.9. Gaceta Oficial No. 14 Extraordinaria, de 13 de agosto de 2003 . el título y diseño de un perfume de la empresa Suchel Camacho S. A., designa una competencia bádminton y también un centro de hospedaje en la capital. Los tres atributos comúnmente aparecen en sellos de correo postal y monedas conmemorativas. ${ }^{11}$

La solución de la ley para enfrentar la utilización inadecuada de los símbolos nacionales es el establecimiento de una nueva contravención del orden público. Se entiende como tal a la infracción de las normas o disposiciones legales carente de peligrosidad social por la escasa entidad de sus resultados. ${ }^{12}$ La Disposición Transitoria Única establece la posibilidad de amonestar a las personas cuando no guarden el respeto que se merecen los símbolos nacionales en ocasión de actos oficiales o encontrándose en espacios públicos. Por ello serán objeto de una notificación preventiva o multa de 200 pesos, siempre que dichos actos no sean constitutivos de delitos. El Ministerio del Interior es el encargado de cumplimentar la disposición y, por ende, los oficiales de la policía los sujetos delegados para ejecutarla.

11. Mediante disposiciones del Ministerio de las Comunicaciones y en sellos de correos: la palma real (Resolución No. 26, de 26 de febrero de 2007 en Gaceta Oficial No. 21 Ordinaria de 23 de marzo de 2007; Resolución No. 146, de 6 de diciembre de 2010 en Gaceta Oficial No. 053 Ordinaria de 21 de diciembre de 2010 y Resolución No. 197, de 3 de julio de 2017 en Gaceta Oficial No. 39 de 30 de noviembre de 2017), el tocororo (Resolución No. 84 de 8 de agosto de 2005 en Gaceta Oficial No. 51 Ordinaria de 28 de octubre de 2005 y Resolución No. 147, de 27 de septiembre de 2011 en Gaceta Oficial No. 034 Ordinaria de 21 de octubre de 2011 y Resolución No. 386 de 29 de abril de 2014 en Gaceta Oficial No. 23 Ordinaria de 23 mayo de 2014) y la flor de la mariposa (Resolución No. 310, de 7 de octubre de 2013 en Gaceta Oficial No. 054 Ordinaria de 1 de noviembre de 2013 y Resolución No. 139, de 11 de junio de 2015 en Gaceta Oficial No. 29 Ordinaria de 3 de julio de 2015). La figura del ave nacional también aparece en una moneda conmemorativa según Instrucción No. 35, de 30 de marzo de 2017, del Banco Central de Cuba en Gaceta Oficial No. 26 Ordinaria de 28 de septiembre de 2017.

12. Decreto-Ley No. 99 "De las contravenciones personales", de 25 de diciembre de 1987, Artículo 1. En el sistema de contravenciones, además de la multa, pueden imponerse otras medidas: obligación de hacer lo que impida la continuidad de la conducta infractora o lo necesario para restituir las cosas a su estado anterior a la contravención; suspensión definitiva o temporal, o modificación, de licencias, permisos o concesiones otorgados de conformidad con la legislación vigente; y decomiso de los instrumentos o efectos de la contravención Las contravenciones prescriben de inmediato, al no procederse contra ellas cuando sean conocidas al momento mismo de su comisión, o cuando, ya cometidas, sus efectos dejen de subsistir en el momento de la comprobación. Por la comisión de las contravenciones se responde administrativamente, con independencia de cualquier otra responsabilidad civil o material. 
La expresión "no guardar el respeto que se merecen los símbolos nacionales en espacios públicos", deviene muy subjetiva para su interpretación por las autoridades policiales. Si se tiene en cuenta el uso masivo de los símbolos nacionales en el país actualmente, el aumento de multas por concepto de la ley es muy probable. Con ello se crea una situación jurídica bastante compleja: la concurrencia de responsabilidad administrativa y civil o penal según sea el caso. Sin embargo, el autor considera oportuno evitar la intervención punitiva del Derecho: una actitud preventiva del sistema educacional y los medios de comunicación en la promoción de valores; así como una postura proactiva del Ministerio de Cultura en el seguimiento a la producción cultural comercializable y la Aduana General de la República en la importación de bienes que burlan lo establecido en la Ley de Símbolos Nacionales.

$\mathrm{Si}$ la conducta es socialmente peligrosa el código penal vigente establece sanción de privación de libertad de tres meses a un año o multa de 100 a 300 cuotas al que ultraje o con otros actos muestre desprecio a la bandera, al himno o al escudo nacional. ${ }^{13}$ Como se evidencia, no quedan incluidos los atributos. En esta figura penal, el bien jurídico protegido es el orden público, pero entraña valores como la identidad nacional, el patriotismo y la independencia por solo mencionar algunos. Es cuestionada esta tipificación penal pues la formación de valores es más inherente del sistema educacional que del Derecho penal, caracterizado entre otros elementos, por ser el instrumento estatal de

13. Ley No. 62 “Código Penal", artículo 203, de Gaceta Oficial No. 3 Especial, de 30 de diciembre de 1987, modificada por la Ley No. 87 publicada en Gaceta Oficial No. 1 Extraordinaria de 15 de marzo de 1999. control social más intenso, lo cual exige que su uso esté siempre al servicio de la salvaguarda de los derechos y bienes con protección constitucional clara (Cossío, 2006, 61).

Finalmente, el autor estima la inaplicabilidad de la teoría de la unidad y pluralidad de delitos con el artículo 227 incisos d) y e). Como los símbolos nacionales no pueden constituir ninguna modalidad de la propiedad industrial, sería motivo de casación por infracción de ley considerar también las conductas tipificadas en el mencionado precepto, a pesar de que el bien jurídico protegido sea distinto, en este caso, el derecho del consumo en clara relación con la propiedad industrial.

\section{CONCLUSIONES}

La protección jurídica que en Cuba se le otorga a los símbolos nacionales se encuentra en diferentes esferas del ordenamiento legal. La tutela en sede de la propiedad intelectual está caracterizada por un sistema de pautas orientadas a limitar o prohibir el uso de los símbolos nacionales. En cambio, la utilización de los atributos es mucho más permisiva debido a la inexistencia de normas.

La nueva ley de símbolos nacionales refuerza la protección a estos elementos distintivos, sobre todo en el ámbito de la propiedad intelectual. Se modernizan las disposiciones jurídicas al respecto y se adiciona como contravención personal las violaciones a su contenido. Sin embargo, todavía persisten manifestaciones antijurídicas en los actos mercantiles del sector estatal y privado. La aplicación de la ley deberá ir aparejada de una amplia difusión por los medios de comunicación y enseñanza en los diferentes niveles educacionales.

\section{BIBLIOGRAFÍA}

\section{Doctrina}

- Alegre Martínez, M. (2011). Los símbolos políticos: su entidad cultural, representativa e integradora.

- Ciudad de León: Repositorio institucional de la Universidad de León.
- Amaro Cano, M. (2014). Una aproximación a los valores éticos consensuados por la sociedad cubana. Educación Médica Superior 28, (1), 35-49.

- Cossío Díaz, J. y Siva Meza, J. Libertad de expresión y símbolos patrios. (2006). Letras Libres 8 (85), 60-65. 
- García Arango, G. (2013). El deber y el derecho de amar la patria. Pensamiento Jurídico (37), 213-241.

- Garza, J. (2006). Ultraje a las insignias nacionales vs. La libertad de expresión (la bandera nacional: símbolo de libertad). EN: D. Cienfuegos Salgado y Macías Vázquez, M., ed., Estudios en homenaje a Marcia Muñoz de Alba Medrano. Protección de la persona $y$ derechos fundamentales. Universidad Nacional Autónoma de México.

- González Alcantud, J. (2003) Bandera(s), patria(s), himno(s). Recorrido emocional y comparado por los símbolos nacionales español y francés en el marco pre y paneuropeísta. Historia, Antropología y Fuentes Orales (30), 133-151.

- Leal Spengler, E. (2016) ¿Qué sentido tiene la bandera de una nación? Recuperado de: http://bit.ly/31El8Bv, consultado el 21 de enero de 2019.

- Rodríguez García, M.; Corrales-Reyes, I.; Fornaris-Cedeño, Y.; García Raga, M., \& Izaguirre Remón, R. (2017). Perucho Figueredo: insignia de himno y de patria libre. Revista 16 De Abril, 56(266), 194-203. Recuperado de http://bit.ly/2UGwIKO

- Troncoso Reigada, A. (2018). La bandera y la capitalidad. Revista de Derecho Político, (103), 29-76.

\section{Legislación}

- Asamblea Nacional del Poder Popular de la República de Cuba: Fundamentos del Proyecto de Ley de Símbolos Nacionales, disponible en: http://www.cubahora. cu/uploads/documento/2019/03/11/ fundamentacion-del-proyecto-de-ley-delos-simbolos-nacionales.pdf, consultado el 10 de enero de 2019, hora: 13:20. Proyecto de Ley de Símbolos Nacionales, disponible en: http://www. parlamentocubano.gob.cu/wp-content/ uploads/PROYECTO-DE-LEY-DE-LOSSIMBOLOS-NACIONALES-Version-V.pdf, consultado el 10 de enero de 2019, hora: 13:30.

- Congreso de los Diputados de España, Proposición de Ley relativa a la defensa de la convivencia social, la neutralidad institucional y los símbolos nacionales, de 14 de septiembre de 2018, disponible en: http://www.congreso.es/public_oficiales/ L12/CONG/BOCG/B/BOCG-12-B-309-1. PDF, consultado el 25 de enero de 2019, hora: 09:00.

- Constitución de la República de Cuba. Gaceta Oficial No. 5 Extraordinaria de 10 de abril de 2019.

- Decreto No. 268 "Contravenciones de las regulaciones forestales", de 8 de septiembre de 1999 en Gaceta Oficial No. 58 Ordinaria de 17 de septiembre de 1999.

- Decreto-Ley No. 99 "De las contravenciones personales", de 25 de diciembre de 1987.

- Decreto-Ley No. 203 "De las marcas y otros signos distintivos", de 24 de diciembre de 1999. Gaceta Oficial No. 3 Extraordinaria de 2 de mayo de 2000.

- Decreto-Ley No. 228 "De las indicaciones geográficas", de 20 de febrero de 2002. Gaceta Oficial No. 11 Ordinaria de 22 de febrero de 2002.

- Decreto-Ley No. 290 "De las invenciones y dibujos y modelos industriales", de 20 de noviembre de 2011. Gaceta Oficial No. 002 de 1 de enero de 2012.

- Decreto-Ley No. 352 "Sobre la adquisición de la ciudadanía cubana por nacimiento de los nacidos en el extranjero de padre o madre cubanos", de 30 de diciembre de 2017. Gaceta Oficial No. 63 Extraordinaria, de 30 de diciembre de 2017.

- Instrucción No. 35, de 30 de marzo de 2017, del Banco Central de Cuba en Gaceta Oficial No. 26 Ordinaria de 28 de septiembre de 2017.

- Ley No. 62 "Código Penal”, artículo 203, de Gaceta Oficial No. 3 Especial, de 30 de diciembre de 1987, modificada por la Ley No. 87 publicada en Gaceta Oficial No. 1 Extraordinaria de 15 de marzo de 1999. 
- Ley No. 85 "Ley Forestal", de 21 de julio de 2018, Gaceta Oficial No. 46 de 31 de agosto de 1998. Resolución No. 330 Reglamento de la Ley Forestal, de 7 de septiembre de 1999, del Ministerio de Agricultura, en Gaceta Oficial No. 57 Ordinaria de 10 de septiembre de 1999.

- Ley No. 128 “Ley de los Símbolos Nacionales de la República de Cuba", de 13 de julio de 2019. Gaceta Oficial No. 71 Ordinaria de 19 de septiembre de 2019.

- Ley No. 128 "Ley de los Símbolos Nacionales de la República de Cuba", de 13 de julio de 2019. Gaceta Oficial No. 71 Ordinaria de 19 de septiembre de 2019.

- Resolución No. 84 de 8 de agosto de 2005, del Ministerio de las Comunicaciones en Gaceta Oficial No. 51 Ordinaria de 28 de octubre de 2005.

- Resolución No. 139, de 11 de junio de 2015, del Ministerio de las Comunicaciones en Gaceta Oficial No. 29 Ordinaria de 3 de julio de 2015.

- Resolución No. 146, de 6 de diciembre de 2010, del Ministerio de las Comunicaciones en Gaceta Oficial No. 053 Ordinaria de 21 de diciembre de 2010.

- Resolución No. 147, de 27 de septiembre de 2011, del Ministerio de las Comunicaciones en Gaceta Oficial No. 034 Ordinaria de 21 de octubre de 2011.

- Resolución No. 160 "Regulaciones para el control y la protección de especies de especial significación para la diversidad biológica del país", de 28 de junio de 2011 del Ministerio de Ciencia, Tecnología y Medio Ambiente, según Gaceta Oficial No. 026 Ordinaria de 4 de agosto de 2011.

- Resolución No. 169 que aprueba la lista oficial de variedades vegetales comerciales, de 17 de marzo de 2017, del Ministerio de la Agricultura en Gaceta Oficial No. 18 Ordinaria de 16 de junio de 2017.

- Resolución No. 197, de 3 de julio de 2017, del Ministerio de las Comunicaciones en Gaceta Oficial No. 39 de 30 de noviembre de 2017.

- Resolución No. 200 del Ministerio de la Construcción sobre la Regulación de la Construcción RC 1081.2018 relativa a los requisitos de proyectos y de calidad de los materiales a emplear en las nuevas inversiones de carácter turístico, recreativo, agrícola y de viviendas de la Gaceta Oficial No. 49 Ordinaria de 13 de diciembre de 2018.

- Resolución No. 201 del Ministerio de Comercio Interior, Aprueba Lineamientos Generales para el Programa de Comunicación Comercial de las Entidades que Participan en el Mercado Interno en Divisas, de 2 de junio de 2003. Gaceta Oficial No. 14 Extraordinaria, de 13 de agosto de 2003.

- Resolución No. 310, de 7 de octubre de 2013, del Ministerio de las Comunicaciones en Gaceta Oficial No. 054 Ordinaria de 1 de noviembre de 2013.

- Resolución No. 386 de 29 de abril de 2014, del Ministerio de las Comunicaciones en Gaceta Oficial No. 23 Ordinaria de 23 mayo de 2014.

\section{Jurisprudencia}

- Tribunal de Justicia de la Unión Europea, Sentencia No. C-202/08, de 12 de mayo de 2009, Conclusiones del Abogado General

- Tribunal Supremo de España, Sala de lo Contencioso, Recurso No. 4280, de 4 de marzo de 2013, Juez Ponente José Díaz Delgado. 


\title{
OS EFEITOS DA ALTERAÇÃO DE GÊNERO E AS FORÇAS ARMADAS BRASILEIRAS: NECESSIDADE DE ADEQUAÇẤO AO NÚCLEO AXIOLÓGICA CONSTITUCIONAL*
}

\author{
Los efectos del cambio de género y las Fuerzas Armadas \\ brasileñas: necesidad de adecuación al núcleo axiológico \\ constitucional

\begin{abstract}
The effects of gender change and Brazilian Armed Forces: the need of the forces to fit the constitutional axiological core
\end{abstract}

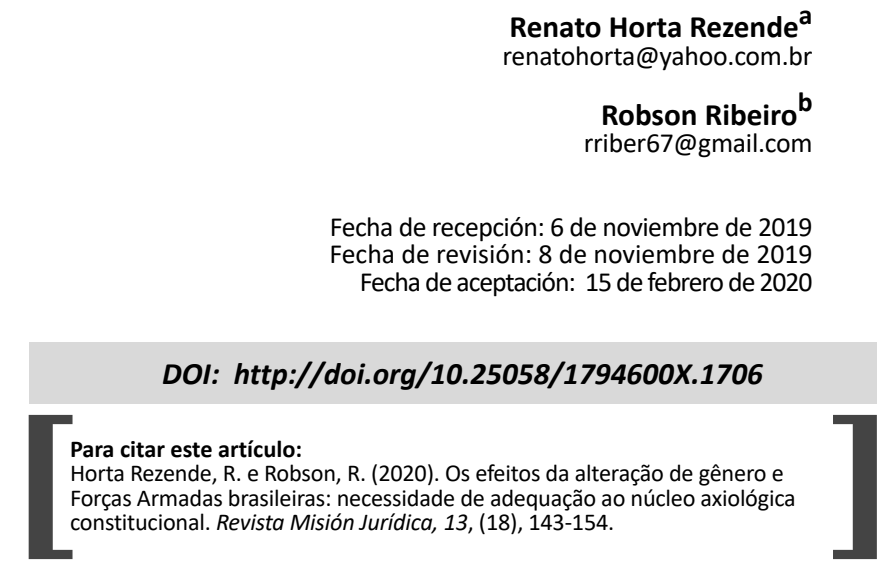

\section{RESUMO}

Com a evolução conceitual e classificatória da transexualidade nas ciências médicas e o desenvolvimento do tema também no Direito, resta observar qual o tratamento jurídico concebido pelas Forças Armadas brasileiras aos militares ou a seus dependentes transgêneros. Diante do problema foi investigada hipótese que considera qualquer afastamento motivado exclusivamente pela transexualidade como inválida a luz dos direitos fundamentais e objetivos da República de 1988, independentemente da época em se der o registro da mudança de gênero em virtude de sua natureza declaratória, fato que também repercute no benefício concedido sobre o critério binário (masculino e feminino) a dependentes. A pesquisa possuiu como referencial teórico a Constituição da República de 1988, tendo sido executada por meio do método hipotético-dedutivo, primordialmente

\footnotetext{
* Artículo de reflexión.

a. Professor de disciplinas afins ao Direito no Centro Universitário UNA (2018 até os dias atuais); Professor do Curso de Direito na Faculdade Pitágoras (2018-2019); Professor do Curso de Direito da FACISA/MG (2018); Diretor da Comissão de Direito das Famílias da OAB-Minas (2019-2021); Mestre em Direito pelo Programa de Pós-graduação em Direito da Universidade Fumec (2016); Especialização em ciência criminais na Faculdade Arnaldo Janssen (2018); graduado em Direito pela Fundação Universidade de Itaúna (2004); Advogado inscrito na Seccional Minas Gerais há treze anos (2005); Professor do CEB-CECON (2007-2011); Professor no CFDs da APMMG (2014); Professor de arbitragem, mediação e conciliação junto ao Conselho Estadual de Arbitragem de Minas Gerais (2009-2018), Árbitro inscrito no CONFEJAB (2015); escritor de livro e vários artigos científicos.

b. Possui graduação em Direito pela Universidade Federal de Uberlândia (2005) e mestrado em Instituições Sociais, Direito e Democracia pela Universidade FUMEC (2017). Atualmente é tabelião - Cartório de Registro Civil e Notas. Tem experiência na área de Direito, com ênfase em Direito Constitucional. Doutorando em Direito Penal pela Universidade Autônoma de Lisboa (2017-2019/2020).
} 
com levantamento bibliográfico, artigos, teses, dissertações, leis e decisões judiciais. A hipótese inicialmente apresentada foi confirmada.

\section{PALAVRAS-CHAVES}

Alteração de gênero; transgênero; Forças Armadas Brasileiras; natureza jurídica; direitos fundamentais; adequação constitucional.

\section{RESUMEN}

Con la evolución conceptual y clasificatoria de la transexualidad en las ciencias médicas y el desarrollo del tema también en el derecho, queda por observar cuál es el tratamiento legal concebido por las Fuerzas Armadas de Brasil a los militares o sus dependientes transgénero. Ante el problema, se investigó una hipótesis que considera inválida cualquier desviación motivada exclusivamente por la transexualidad a la luz de los derechos fundamentales y objetivos de la República de 1988, independientemente del momento en que se registró el cambio de género debido a su naturaleza declaratoria, un hecho que también impactó en el beneficio otorgado en el criterio binario (masculino y femenino) a los dependientes. La investigación tuvo como referencia teórica la Constitución de la República de 1988, que se ejecutó mediante el método hipotético-deductivo, principalmente con encuestas bibliográficas, artículos, tesis, disertaciones, leyes y decisiones judiciales. La hipótesis presentada inicialmente fue confirmada.

\section{PALABRAS CLAVES}

Cambio de género; transgénero; Fuerzas Armadas de Brasil; naturaleza jurídica; derechos fundamentales; adecuación constitucional.

\section{ABSTRACT}

Given the conceptual and classificatory evolution of transsexuality in the medical sciences and the development of the matter also in law, it remains to be observed what the legal treatment conceived by the Brazilian Armed Forces is to the soldiers or their transgender dependents. Faced with the problem, a hypothesis was investigated that considers any suspension motivated exclusively by transsexuality as invalid under the fundamental and objective rights of the 1988 Republican Constitution, regardless of the time when the change of gender was registered due to its declaratory nature. This also impacts the benefit granted on the binary criterion (male and female) to dependents. The research had its as theoretical reference the 1988 Constitution of the Republic, having been executed through the hypotheticaldeductive method, primarily with bibliographic surveys, articles, theses, dissertations, laws and court decisions. The hypothesis initially presented has been confirmed.

\section{KEY WORDS}

Effects; transgender; Brazilian Armed Forces; legal nature; Fundamental Rights.

\section{INTRODUÇÃO}

A evolução do conceito e classificação do transexualismo junto a ciências médicas e no ordenamento jurídico pátrio e internacional, somando aos fundamentos e objetivos da República do Brasil de 1988 enumerados em sua Constituição, criaram novas perspectivas sob o tema e afloram questões até então ignoradas pelas maiorias.

0 julgamento da Ação Direta de Inconstitucionalidade (ADI) no 4.275, proferido pelo Supremo Tribunal Federal (STF) em 01 de março de 2018, seguido do Provimento no 73, de 28 de julho de 2018, autorizou os Cartórios de Registro Civil das Pessoas Naturais a alterarem, mediante auto-declaração, o nome e gênero do interessado, independente de laudo ou procedimento cirúrgico prévio, desjudicializando e inserindo a questão no âmbito da autonomia privada, tornado o procedimento mais simples e célere.

A alteração do gênero no assento civil das pessoas naturais possui amplos reflexos e a evolução acima mencionada não representa o fim das dificuldades impostas, principalmente em corporações tradicionalmente dirigidas ao gênero masculino, sendo importante investigar qual o tratamento jurídico concebido pelas Forças Armadas brasileiras aos militares ou a seus dependentes transgêneros.

Diante do problema foi investigada hipótese que considera qualquer afastamento motivado exclusivamente pela transexualidade como inválida a luz dos direitos fundamentais e objetivos da República de 1988, independentemente da 
época em se der o registro da mudança de gênero em virtude de sua natureza declaratória, fato que também repercute no benefício concedido sobre o critério binário (masculino e feminino) a dependentes.

O desenvolvimento teórico e investigativo impresso na pesquisa compreendem o método científico hipotético-dedutivo em que foram colhidas premissas amplas por meio de levantamento bibliográfico, artigos, tese e dissertações, investigações sobre conclusões de casos específicos e jurisprudências, para se alcançar respostas específicas, sempre possuindo como referencial teórico a Constituição da República de 1988.

A investigação foi construída em três partes, na primeira foi apresentada definições acerca da evolução do conceito e classificação da identidade de genro e a pessoa transgênras; enquanto a parte seguinte restou dedicada a análise da ADI no 4275 e o Provimento no 73 do CNJ e, posteriormente, foram examinadas as adequações necessárias a que as Forças Armadas brasileiras devem colimar esforços com o objetivo de dar eficácia a direito fundamental e objetivo da República.

\section{A IDENTIDADE DE GÊNERO E AS PESSOAS TRANSGÊNERAS}

Gabriel Saad Travassos (2018, p. 72) arrimado na Opinião Consultiva no 24 de novembro de 2017 da disponibilizada pela Corte Interamericana de Direitos Humanos (CIDH) compreende que a identidade de gênero possui conceituação ampla "que cria espaço para a autoidentificação, e que faz referência à vivência que uma pessoa tem de seu próprio gênero. Assim, ela possui uma multiplicidade de formas (...)".

Maíra Coraci Diniz (2014) evidencia que o gênero não é definido por elementos genéticos, sendo construído pelo meio social, por comportamentos e papéis sociais, cabendo à natureza apenas a definição do sexo.

Mariana Tamara de Lima Oliveira (2018) na mesma esteira dos autores acima citados, adverte que a identidade de gênero não é inata ao indivíduo, ou seja, o reconhecimento como homem ou mulher não é naturalmente decorrente da anatomia e tampouco é estabelecida de modo binário, vindo a afirmar que o gênero é construído com o tempo e sob a influência de fatores variados como, genitália, sociedade, convivência familiar, capacidade cognitiva e fatores culturais, sendo assim resultado de vários fatores, tanto naturais, como sociopsicológicos.

Sob esta última perspectiva é possível definir a identidade de gênero como resultante da confluência de fatores corresponde ao estado psicológico reconhecido pelo indivíduo como seu, independente da realidade anatômica binária, se tratando, pois de uma realidade construída de forma abstrata e individual.

Tangenciando a definição de identidade de gênero proposta, ainda que não exista consenso sobre o termo transgênero, este pode ser conceituado como pessoa que compreende estar em desconformidade entre o sexo anatômico e o gênero por ela percebido, tomado aqui como identidade de gênero (Reinaudo y Bacellar, 2008: 22).

A desconformidade gera na maior parte das pessoas transgêneras grandes conflitos psicológico interno, pois acreditam possuir o sexo anatômico em desacordo com a identidade de gênero auto percebida, como bem leciona Jaqueline Gomes Jesus:

Transgêneras: É a expressão "guarda-chuva" utilizada para designar as pessoas que possuem uma identidade de gênero diferente daquela correspondente ao sexo biológico. Há transgêneros heterossexuais, bissexuais e homossexuais. Neste último caso, a orientação sexual da pessoa transgênera é dirigida para alguém com a mesma identidade de gênero, mas de sexo biológico diferente (2012: s/p)

O conceito acima colacionado é resultante de paulatina evolução nos estudos e classificações sobre a pessoa transexual, que, segundo Tereza Rodrigues Vieira (2008), foi dividida em quatro fases: monomania, nosografia, síndrome e atualmente a disforia de gênero.

A primeira fase dos estudos concebia o transexualimo como resultado de psicose limitada ou delírio, algo próximo a loucura, compreendo-o como uma confusão mental da realidade, enquanto na segunda fase a pessoa transexual passa a ser reconhecida como portadora de anomalia dirigida ao comportamento sexual, à perversão sexual e doente. 
Na terceira fase, a transexualidade é apontada como síndrome, afastando-se a classificação relativa à psicose ou perversão das fases anteriores, sendo compreendida como conjunto de sinais e sintomas observáveis em vários processos patológicos diferentes e sem causa específica, independente do homossexualismo ou do travestismo, mas, ainda assim, vista como doença.

$\mathrm{Na}$ quarta e atual fase, inicialmente foi reconhecida a diferença entre sexo e gênero, enquanto o primeiro designa sexualidade, o segundo relaciona-se com a função do sexo no meio social, vindo em decorrência a ser a transexualidade concebida como a perturbação apresenta entre a identidade de gênero e o sexo anatômico, não sendo mais reconhecida como transtorno mental, mas como incongruência de gênero relacionada à sexualidade.

Atento à quarta fase da evolução do conceito e classificação da transexualidade, o Conselho Federal de Psicologia brasileiro (CFP) editou, em 29 de janeiro de 2018, a resolução no 1 que estabelece normas de atuação para os psicólogos em relação às pessoas transexuais $\mathrm{e}$ travestis fundada na: inexistência de patologia a ser tratada, na necessidade de enfrentamento da transfobia e no caráter autodeclaratório da identidade de gênero, objetivando impedir o uso de instrumentos ou técnicas psicológicas para criar, manter ou reforçar preconceitos, estigmas, estereótipos ou discriminação sobre essa parcela da população (CRP, 2018).

Os apontamentos apresentados acerca da quarta fase evolutiva que inspirou a edição da mencionada resolução do CFP, também foi reconhecida pela Organização Mundial da Saúde (OMS), na 11 a revisão da classificação internacional de doença (CID-11) promovida em 18 de junho de 2018, em que foi afastada a classificação de doença mental atribuída ao transexual e reclassificado o transexualismo como condições relacionadas à saúde sexual, realocada da CID-10 F64 para a CID-11 HA-60, que entrará em 2022:

A incongruência de gênero na adolescência e na idade adulta é caracterizada por uma incongruência acentuada e persistente entre o gênero experiente de um indivíduo e o sexo designado, o que muitas vezes leva a um desejo de 'transição', a fim de viver e ser aceito como pessoa do experiente sexo, por meio de tratamento hormonal, cirurgia ou outros serviços de saúde, para alinhar o corpo do indivíduo, tanto quanto desejado e na medida do possível, com o sexo experiente. 0 diagnóstico não pode ser atribuído antes do início da puberdade. 0 comportamento e as preferências das variantes de gênero, por si só, não são uma base para atribuir o diagnóstico (OMS, 2018).

A perturbação decorrente da incongruência entre o sexo e gênero não surge ou manifesta-se repentinamente, mas ocorre de forma cotidiana e paulatina não sendo possível estabelecer com precisão o momento em que o dilema psicológico se instaura e exsurge o desejo de adequação, ainda que para Sigmund Freud (1856-1939) a identidade de gênero venha a ser definida na vida não adulta (Feist, Feits y Roberts, 2015), já que, principalmente na tenra idade, os fatores sociais estimulantes do conflito não mais intensos.

0 conflito entre a orientação sexual não harmonizada com o sexo anatômico resultante da discordância entre a identidade de gênero e a genitália é agravada pela repercussão e prevalência jurídica do sexo legal, aquele constante em documentos oficiais, que possui como único critério definidor as características anatômicas binária do órgão sexual (OLIVEIRA, 2018) e desconsidera, por conseguinte, a capacidade da pessoa se auto-definir.

Diante da repercussão geral do tema, em respeito ao princípio do direito ao nome, à dignidade da pessoa humana, à personalidade, e à isonomia, o Supremo Tribunal Federal (STF) flexionou a maneira pela qual as pessoas autodeclaradas transgêneras podem solicitar a retificação de seus nomes e gêneros em julgamento proferido na ADI 4.275 (STF, 2018).

Depois da publicação do resultado do julgamento realizado no STF o Conselho Nacional de Justiça (CNJ) publicou o Provimento $73 / 2019$ com a finalidade de instrumentalizar a mencionada decisão proferida que facilitou a conversão do gênero existente no registro civil de pessoas naturais.

Os referidos instrumentos jurídicos trouxeram expressivos avanços adequando-se à realidade médica-científica e ao centro axiológico e fundamento da República, qual seja, a dignidade 
da pessoa humana, objetivando a promoção de todos sem qualquer discriminação.

\section{ADI № 4.275, PROVIMENTO № 73 DO CNJ E OS EFEITO DA NATUREZA JURÍDICA DA ALTERAÇÃO DO PRENOME E DO GÊNERO NO ASSENTO CIVIL DAS PESSOAS NATURAIS}

Constitui objetivo fundamental da república de 1988, dentre outros, a promoção do bem de todos, sem preconceito de sexo ou outras formas de discriminação, preceito que inclui, nas palavras de Britto (2003), certamente inspirada na proposta de Dromi (1997), uma nova perspectiva de igualdade, sedimentada na solidariedade dos povos, na dignidade da pessoa humana e na justiça social instituidora do constitucionalismo fraterno.

Por sua vez, o constitucionalismo fraterno homenageia o pluralismo como valor sociopolíticocultural e tem como pretensão a promoção da integração comunitária das pessoas por meio de uma igualdade civil-moral dos estratos sociais que histórica e dolosamente foram ignorados ou segregados em virtude de uma homogeneidade ficta e marginalizante (Britto, 2003).

Diniz (2014) argumenta sobe os efeitos da homogeneidade que impõe a observação do sistema binário masculino ou feminino não são capazes de agasalhar todos os comportamentos sociais e em função disto produz estereótipos que reforçam um discurso de exclusão e discriminação social dos cidadãos que não se enquadram no padrão estabelecido como decorrente da anatomia, fato que atenta contra os fundamentos e objetivos da República de 1988.

Fundado no constitucionalismo fraterno, assim como em atenção ao princípio constitucional da isonomia material, da livre expressão da autonomia da vontade e da dignidade da pessoa humana, o STF, na Ação Direta de Inconstitucionalidade (ADI) no 4275, autorizou os Cartórios do Registro Civil das Pessoas Naturais a alterarem administrativamente o prenome e o gênero das pessoas autodeclaradas transgêneras, conferindo assim ao art. 58 da Lei no 6.015, de 31 de dezembro de 1973, interpretação conforme a Constituição da República de 1988, estabelecendo condições que facilitaram, popularizaram e ampliaram os pedidos neste sentido.
A decisão proferida pelo excelso STF confirmar a dignidade da pessoa humana como núcleo do ordenamento jurídico brasileiro, além de também estar aliada ao Pacto de São José da Costa Rica (Decreto 678, de 06 de novembro de 1992) que dispõe acerca do direito ao nome, ao reconhecimento da personalidade jurídica, à liberdade pessoal, à honra e à dignidade, sem perder de vista também a Opinião Consultiva no 24 expedida pela CIDH, que estabelece a identidade de gênero como núcleo componente da dignidade da pessoa humana.

A ampliação das possibilidades de alteração de nome e a possibilidade de mudança de gênero promovida pela interpretação dada pelo STF, retiraram do Judiciário o monopólio sobre a definição do indivíduo sobre a sua própria identidade de gênero sendo assim substancial, pois, desjudicializou a questão, até então reservada ao Judiciário, trazendo ainda o mérito para o seio da autonomia privada.

Com o intuito de normatizar a interpretação constitucional apresentada pelo STF na referida ADI, foi publicado em 29 de junho de 2018, o provimento no 73 do CNJ que disciplinou acerca da averbação da alteração do prenome e do gênero nos assentos de nascimento e casamento de pessoa transgênero no Registro Civil das Pessoas Naturais (RCPN), sem a necessidade de apresentação de laudo psicológico ou comprovação de cirurgia de transgenitalização, em respeito à autonomia privada, confirmando que o desejo de transformação não exige a comprovação (laudo) ou ato (cirurgia), até mesmo porque, surge com o tempo sem poder ser apurado precisamente quando.

Todavia, ainda que o tema tenha sido bem disciplinado e possua fundamentos suficientes para sua aplicação, os efeitos decorrentes do reconhecimento da transexualidade ainda geram inúmeros questionamentos, muitos dos quais se relacionam com a natureza jurídica.

Duas hipóteses são levantadas quanto à natureza do reconhecimento jurídico da transexualidade, a primeira atribui à averbação da sentença ou autodeclaração no RCPN natureza constitutiva, operando-se assim efeito ex nunc; todavia, há aqueles que compreendem que a natureza jurídica do ato é declaratória, o que redundaria em efeitos retroativos e prospectivos possuindo como condicionante, em todo caso, também a averbação da sentença ou autodeclaração no RCPN, incorrendo em efeito $e x$ tunc. 
Em ambas as hipóteses têm-se que a simples exteriorização da posse de estado, ou seja, a exteriorização (publicidade) contínua (permanência) e definitiva da condição trans, por si só, não teria eficácia erga omnes sendo indispensável a averbação da sentença ou autodeclaração no RCPN.

Freitas e Vita (2017), fundado no princípio da segurança jurídica, compreendem que a necessária averbação junto ao RCPN possui natureza jurídica constitutiva e efeito ex nunc para não prejudicar os atos jurídicos formados e concluídos antes de constituída a modificação no assento civil, sendo explícito o fundamento consequencialista.

Camila de Jesus Mello Gonçalves (2012), também adepta ao resultado, reconhece a divergência e pouco aprofundamento sobre o tema em solo brasileiro, vindo a informar que nações estrangeiras como a Itália, Inglaterra, Espanha, Bélgica e Portugal reconhecem que tanto do gênero natural como a transexualidade dependerá da época em que for efetuada a inscrição do registro do fato, possuindo natureza jurídica constitutiva e efeito ex nunc.

Todavia, no Brasil não existe disposição legal que explicite a natureza do reconhecimento jurídico da identidade gênero desassociado da anatomia do nascido. Ademais, como acima mencionado, o gênero é construído com o tempo e sob a influência de fatores variados (Oliveira, 2018) não existindo um momento temporal exato para a sua definição e o desejo transexual de mudança, razão pela qual, a auto-declaração de que trata o Provimento $\mathrm{n}$ o 73 do $\mathrm{CNJ}$ ou a sentença judicial declaratória, com fundamento na posse do estado já incorporada à personalidade, que reconhece a identidade de gênero diferente daquela expressada biologicamente, possui, salvo melhor juízo, natureza jurídica declaratória, ou seja, reconhece algo que de fato já existe no mundo da vida e passa, portanto, a ser reconhecida também no âmbito jurídico.

0 reconhecimento jurídico sobre algo já existente que altera elemento de identificação formal no registro civil adequando-o à realidade não pode ignorar a anterior inadequação para então gerar efeitos apenas subsequentes ao registro civil, justamente por possuir existência prévia ao ato formal meramente declaratório sobre o qual deve-se impor efeito ex tunc.

A definição da natureza e os efeitos jurídicos possuem repercussão relevante no mundo jurídico, tanto nas relações privadas atinentes ao casamento, por exemplo, como também nas relações públicas relativas à seguridade social, Lei Maria da Penha, feminicídio, execução penal e forças armadas.

A evolução conceitual, classificatória e jurídica sobre o transexual não representa o fim das dificuldades impostas às pessoas transgêneras, pois a questão é complexa e muitas vezes atrelada ao preconceito que tem como alvo as minorias (Moura y Lopes, 2014), fato que agravados pelos conflitos internos, falta de informação, preconceito social, ou pela morosidade judicial, faz com que inúmeras pessoas ingressam nos quadros da Administração Pública ou no mercado de trabalho antes de iniciar o processo de transformação física e/ou alteração de nome e gênero em seus documentos de identificação.

Assim, os transgêneros podem vir a iniciar suas respectivas vidas profissionais com o gênero diverso do que possuem atualmente em seus documentos, fato que além do constrangimento inerente a situação, pode resultar em dificuldades ou até mesmo impedimento de exercer atividades ou gozar de direitos assegurados, como veremos nos casos dos militares das forças armadas brasileira e seus dependentes.

\section{A NECESSIDADE DE ADEQUAÇÃO DAS FORÇAS ARMADAS AOS PRINCÍPIOS CONSTITUCIONAIS E A CONDIÇÃO DO TRANGÊNERO}

As normas constitucionais situam-se em um conjunto maior e modular que traçam linhas gerais que devem repercutir em todo o restante do direito, possuindo assim posição privilegiada, efetivada por meio da jurisdição constitucional, exigido do interprete das normas infraconstitucionais e atos os operadores um sentido de adequação, somente se justificando ações e interpretações à luz da Constituição (Fernandes, 2018).

A ausência da referida adequação acima dardejada macula o ato, o tornado inválido e contrário a ordem constitucional, lógica esta que estrutura o atual constitucionalismo que sustenta o ordenamento jurídico brasileiro (Rezende, 2017), portanto, algo relacionado a sua sustentabilidade e credibilidade.

A adequação exigida deve-se operar nos atos praticados por particulares e também por 
toda a Administração (Fernandes, 2018), pois não assentado apenas em fundamentos éticofilosóficos, mas também exigindo eficácia (Sarlet, 2018), não se admitindo o tratamento contrário à dignidade da pessoa humana, à personalidade ou à isonomia, sob pena de invalidade, sendo importante examinar práticas promovidas pelas Forças Armadas brasileiras frente à situação dos transgêneros e a luz do ordenamento jurídico vigente.

\subsection{Reforma compulsória}

O Inquérito Civil n. - 1.30.001.000522/201411 conduzido pelo Ministério Público Federal (MPF) apurou situações em que pessoas foram sistemática e compulsoriamente reformadas sob o fundamento da incapacidade para o serviço ativo militar por sua condição ou opção sexual (MPF, 2017).

Em todos os quatro casos investigados pelo MPF pessoas foram excluídas do serviço ativo das Forças Armadas brasileiras após confirmarem a intenção de realizar transição de gênero, mesmo tendo manifestado inequívoco desejo de permanecer nas fileiras militares, estarem aptas para o exercício de atividades e possuírem qualificação suficiente.

Como fundamento a decisão que conduziu os militares a inatividade, as Forças Armadas brasileiras apresentaram parecer biomédico cujo diagnóstico era o transexualismo, CID$10 \mathrm{~F} 64$, asseverando este como justificativa ao afastamento do militar de suas atividades somada à ausência de posto adequado para lotação feminina, ainda que, no mesmo parecer existisse confirmação do exercício regular e qualificação suficiente para realização de atividades militares.

Ainda que as Forças Armadas brasileiras adotem perspectivas médicas, amparada na CID-10, ainda em vigor no Brasil, sobre a transexualidade, tem-se que além de inadequada frente à quarta fase da evolução sobre o tema, também contraria frontalmente 0 princípio constitucional da dignidade da pessoa humana, epicentro axiológico de todo o ordenamento jurídico pátrio, assim como também contrário aos ditames do Pacto de São José da Costa Rica que proíbe a marginalização baseada na orientação sexual ou de qualquer outra natureza discriminatória, inclusive identidade de gênero.
A justificativa relativa à inexistência de posto de trabalho para o militar transgênero, ou seja, de gênero feminino, afronta a isonomia constitucional, assim como o art. 70 da Lei $\mathrm{n}^{\mathrm{o}}$ 12.705 , de 08 de agosto de 2012, que trata acerca dos requisitos para ingresso nos cursos de formação de militares de carreira especificamente do Exército, e determina a viabilização do ingresso da candidata do sexo feminino na linha militar bélica.

Como afirmado em capítulo anterior, a identidade de gênero é construída paulatinamente e influenciada por vários aspectos, quando somente após, poderá ser manifestado o desejo de transposição, portanto as ações praticadas pelo militar no exercício da função quando ainda não exteriorizada a sua transexualidade, mas já interiorizada, não foi alterada após a revelação da identificação do gênero, justamente porque, não é o fato de se revelar ou promover a alteração no assento civil do nome e/ou do gênero que constitui ou institui a percepção do ser.

Assim, o fato do militar se autodeclarar na forma do Provimento no 73 do CNJ ou judicialmente, não tem o condão de alterado a capacidade para o exercício militar que já desempenhava justamente porque não é o referido ato que o tornou transexual, mas apenas declarou a auto-identificação, fato que não justifica substancialmente qualquer afastamento dos serviços militares.

Todavia, a situação apurada pelo MPF no referido Inquérito Civil que apurou a reforma de militares em virtude da transexualidade, também é enfrentada repetidas vezes pelo Judiciário ${ }^{1}$ que de forma pacífica compreende não ser adequada a determinação do afastamento das atividades exclusivamente em virtude da condição da pessoa transgênera.

Ainda assim, reforma ou reserva compulsória são impostas ao militar que revele ser transgênero, fato que levou o MPF a utilizar da competência a que aludem o art. 6으, XX da Lei complementar no 75 de 20 de maio de 1993 , assim como no art. 27, parágrafo único, IV, Lei no 8.625 de 12 de fevereiro de 1993, e art. 15, da

1. Vg: Processo $n^{-}$0210689-57.2017.4.02.5101; processo $n^{\circ}$ 0000511-73.2018.4.02.0000; Processo $n^{\underline{0}}$ 000051173.2018.4.02.0000 todos juntos ao TRF 2 a região. 
Resolução no 23 de 17 de setembro de 2007, do Conselho Nacional do Ministério Público (CNMP) a expedir a recomendação $\mathrm{PRDC} / \mathrm{RJ} / \mathrm{n}$ o 04 , em 21 de novembro de 2017 ao comando do Exército brasileiro, para que exima-se de repetidas ações que contrariam dispositivos constitucionais, convencionais e legais conforme colacionado:

A) que a transexualidade não seja considerada como motivo determinante para a reforma de militares, nem como forma de incapacidade para o exercício da atividade militar;

B) que sejam estabelecidos programas de reabilitação ou transferência de militares transexuais em funções compatíveis em outros Corpos ou Quadros das Forças Armadas, caso exerçam originalmente funções que não podem ser ocupadas por mulheres;

C) que sejam implementados programas de combate à discriminação, voltados à erradicação da homofobia e transfobia, de modo a não excluir das Forças Armadas as pessoas transgênero ou homossexuais (MPF, 2017).

Os casos examinados no Inquérito Civil n.o 1.30.001.000522/2014-11 que justificaram a expedição da recomendação no 04 de 2017 acima, assim como as ações judiciais que tratam do mesmo tema apresentam o quadro fático preocupante e sistemático de desrespeito pelas Forças Armadas brasileiras dos princípios constitucionais, convencionais e regras infraconstitucionais, desconsiderando também a capacidade ativa do exercício das ações militares, fato que demonstram como ainda são necessárias ações afirmativas e repressivas sobre o tema para que não se tornem preceitos meramente teóricos ou promessas vazias.

\subsection{Pensão por morte para filha solteira e capaz de militar e a situação do trangênero}

Os militares das Forças Armadas brasileiras possuem regras diferenciadas com relação a benefícios auferidos na inatividade ou atribuídos aos seus dependentes, regulados pela Lei de pensões, no 3.765 , de 04 de maio de 1960 , pelo Estatuto dos militares, Lei no 6.880, de 09 de dezembro de 1980 e pela Medida Provisória que reestrutura a remuneração dos militares, no 2.215-10, de 31 de agosto de 2001.
0 parágrafo único do art. $3^{3}$ da Lei $\mathrm{n}^{\mathrm{o}}$ $3.765 / 1960$ fixa alíquota de sete e meio por cento do soldo para custeamento das pensões por morte pagas a dependentes, cônjuge; companheiro; ex-cônjuge ou ex-companheiro beneficiário de pensão alimentícia; filhos, enteados, menor sob guarda ou maior tutelado até vinte e um anos de idade ou vinte e quatro anos de idade se universitário, ou por prazo indeterminado enquanto perdurar incapacidade.

A Medida Provisória 2215-10/2001, ainda em vigor por determinação do art. $2^{\circ}$ da Emenda Constitucional no 32, de 11 de setembro de 2001, extinguiu a instituição de novas pensões por morte por prazo vitalício a serem pagas para filhas dos militares que ingressaram na carreira militar após a publicação da referida medida provisória.

No entanto, a mencionada medida provisória manteve o benefício da pensão por morte já concedida às filhas solteiras de qualquer idade face ao ato jurídico perfeito e concedeu a faculdade aos militares que ingressaram nas Forças Armadas antes da publicação da medida a manter o potencial benefício às suas dependentes mediante a contraprestação doravante equivalente a um e meio por cento do soldo.

A manutenção do referido benefício ou a potencial concessão às beneficiárias, filhas de militares que iniciaram sua carreira antes da mencionada medida provisória está submetido ao modelo binário que trata de forma diferente homens e mulheres, isto porque, ao dependente filho-homem na mesma situação que a dependente filha-mulher, ou seja, capaz e solteiro não é ou será concedido pensão por morte vitalícia.

Estando atrelado ao modelo binário (gênero masculino ou feminino) novamente a questão do transgênero se apresenta como situação que exige maior e melhor reflexão garantindo-se a efetiva aplicação dos direitos e garantias constitucionais.

Primeiramente há que se destacar, conforme anotado acima, que o modelo binário mencionado possui como critério o gênero, masculino ou feminino, cuja sua identidade é definida não pela anatomia, mas por fatores variados (Oliveira, 2018), sendo, portanto possível haver diferença entre a identidade de gênero percebida e a verificada biologicamente (Jesus, 2012), esta última inicialmente definida como sexo legal. 
Todavia, ocorrendo alteração do gênero no registro civil das pessoas naturais, por ato autodeclaratório ou adjudicado, haverá reflexos na concessão ou interrupção da pensão por morte vitalícia a filha de militar.

Novamente a definição da natureza jurídica do ato que reconhece transexualidade e os efeitos decorrentes é de suma importância para identificar o direito a ser aplicado, ou seja, o reconhecimento do ato como constitutivo ou declaratório irá influir na eventual concessão, manutenção ou não do benefício.

Compreendendo que a auto-declaração a que trata o Provimento no $73 / 2018$ do CNJ ou a sentença que reconhece o transgênero possui natureza jurídica declaratória e efeitos ex tunc deve ser observado o reconhecimento do gênero em assento civil na data do requerimento de benefício, podendo ser alterado tanto o gênero como eventual deferimento ou indeferimento do pedido de concessão de benefício.

Assim, pessoa transgênera, anatomicamente identificada como do sexo masculino, caso se reconheça como do sexo contrário e venha a se enquadrar nos demais critérios legais teria direito a perceber o benefício, assim como a alteração em sentido contrário supriria o direito do beneficiário.

Ainda em atenção à natureza jurídica da auto-declaração ou da decisão adjudicada os efeitos devem ser observados também em seu aspecto retroativo, ou seja, mesmo que na época do falecimento do militar, o filho não tenha promovido a retificação no registro civil das pessoas naturais, porém, venha a praticar a alteração em momento posterior, possuindo também os demais requisitos, fará jus à percepção do benefício, condicionada, porém, a percepção das prestações mensais à prescrição quinquenal, conforme determinação contida no art. 71 do Decreto no 49.096, de 10 de outubro de 1960 que regulamenta a Lei no 3.765/1960.

Da mesma forma, a alteração formal da identidade de gênero, feminino para masculino, teria o condão de afastar o direito a percepção de potencial ou mesmo o benefício já instituído.

Compreensão semelhante à acima apresentada foi utilizada em julgado proferido pelo MM juiz
Frederico Montedonio Rego, lotado na 7a Vara da Justiça Federal seção Rio de Janeiro, em 13 de setembro de 2017:

Ao comparecer à Marinha no corrente ano para recadastramento periódico, tendo em vista a continuidade da percepção da pensão ("prova de vida"), o impetrante, hoje com 54 anos de idade, apresentou seus documentos atuais, em que consta seu nome social masculino. Assim, seu benefício foi cancelado, pois entendeu a autoridade impetrada que os dispositivos da Lei no 3.765/1960 "limitam ao filho do sexo masculino o direito à reversão até 21 anos de idade ou até 24 anos de idade, se estudante universitário.

[...]

Portanto, entender que o impetrante seria titular do direito à pensão seria considerá-lo, em alguma medida ou para certos fins, como um indivíduo do sexo feminino, o que reavivaria todo o sofrimento que teve durante a vida e violaria sua dignidade, consubstanciada no seu direito - já reconhecido em juízo - a ser reconhecido tal como é para fins jurídicos, ou seja, como um indivíduo do sexo masculino.

[...]

Assim, agiu com correção a autoridade impetrada ao cancelar a pensão, como também agiria na situação hipotética inversa, se concedesse o benefício a uma requerente identificada com o gênero feminino, apesar de nascida com o sexo masculino. A propósito, não há um problema de direito intertemporal, porque a sentença de fls. 65/68 é meramente declaratória do gênero com o qual o impetrante sempre se identificou desde a infância, tendo apenas legitimado essa situação para fins jurídicos. De toda forma, ainda que se entenda diferentemente, o impetrante deixou de preencher um dos requisitos essenciais para a percepção da pensão, o que autoriza o seu cancelamento. Não é inédita no direito a revisão de benefícios concedidos em razão de uma condição em princípio permanente, mas cuja mudança é incompatível com a continuidade da prestação (e.g., a recuperação da capacidade laborativa implica a cessação de aposentadoria por invalidez). [...]

Embora a presente decisão seja patrimonialmente desvantajosa para o impetrante, ela legitima sua identidade de gênero e sua condição existencial, aspecto mais importante e que deve ser levado a sério em todas as suas consequências (Mandado de Segurança, no 0155101-65.2017.4.02.5101, s/p). 
Verifica-se no fragmento acima que o referido juiz considerou a situação da transexualidade sob a dimensão dos direitos fundamentais assim como os efeitos da sentença declaratória de reconhecimento transexual, compreendendo ser possível a revisão de benefícios concedidos em razão da alteração é incompatível com a continuidade da prestação, mesmo ocorra desvantagem patrimonial.

Na decisão judicial em análise, o magistrado admitiu também que o benefício relativo à pensão por morte de filha solteira de militar teria natureza jurídica previdenciária e não securitária, sendo assim possível a sua reversão.

Ainda que exista divergência sobre a natureza jurídica dos benefícios concedidos aos militares e seus beneficiários, o qual se encontra para além do recorte proposto por este artigo, é importante destacar que a reversão do benefício concedido em virtude da alteração de gênero no assento civil de registro de pessoas naturais tem efeitos apenas prospectivos em virtude de sua condição assistencial e em homenagem à segurança jurídica, não se aplicando o mesmo raciocínio relativo à natureza jurídica do ato que altera o gênero escrito no assento do registro civil das pessoas naturais justamente por serem objetos jurídicos totalmente diferentes.

\section{CONCLUSÃO}

A transexualidade atualmente apresentada constitui resultado de longa evolução tanto social e jurídica como médico-científica não sendo atualmente conceituada nem tampouco classificada como doença.

0 STF na ADI no 4.275, reconhecendo a diferença entre sexo e gênero, assim como aplicando o princípio da isonomia, direito à personalidade e à dignidade da pessoa humana, autorizou os Cartórios do Registro Civil das Pessoas Naturais a alterarem administrativamente o prenome e o gênero das pessoas autodeclaradas transgêneras conferindo assim ao art. 58 da Lei no . 6.015, de 31 de dezembro de 1973, interpretação conforme a Constituição da República de 1988, desjudicializando a questão até então reservadas ao Judiciário.

Diante da necessidade de efetividade do direito fundamental à personalidade, o objetivo de não discriminação e sob o fundamento da República da dignidade da pessoa humana, o $\mathrm{CNJ}$ regulou os efeitos instrumentais da decisão proferida pelo STF por meio do Provimento no 73.

Ainda que exista divergência, a auto-declaração firmada pelo transgênero ou a sentença judicial declaratória possui efeitos ex tunc fato que repercute na esfera jurídica de diversos ramos do Direito e na realidade coorporativa de instituições tradicionais como as Forças Armadas brasileiras.

Ainda que as mudanças normativas venham a facilitar a alteração nos assentos civis de pessoas naturais e inserir pessoas que estavam à margem, de fato, os reflexos do ato podem impor restrições discriminatórias contrárias ao fundamento e aos objetivos da República mesmo dentro da Administração, como ocorre junto às Forças Armadas brasileiras que praticando atos discriminatórios impõem reformas compulsórias aos militares em virtude da transexualidade em afronta a dignidade da pessoa humana, bem como a direitos convencionais e infraconstitucionais.

A reforma compulsória imposta aos transexuais além de afrontar o Direito também se mostra ilógica, pois o desejo de alteração do gênero no registro civil das pessoas naturais com ou sem a submissão a cirurgia de transgenitalização tem como objetivo dar publicidade à identidade de gênero que a pessoa, já integrante das Forças Armadas, possuía não se justificando o afastamento por este motivo quando presente a capacidade e adequação às atividades militares.

A mudança de gênero no assento civil das pessoas naturais também possui reflexo na concessão de pensão por morte à filha de militares solteiras de qualquer idade, isto porque, um dos critérios para concessão de benefício é justamente o binário (masculino ou feminino), devendo ser observado o gênero constante no registro civil da pessoa natural na época do requerimento do benefício independente da alteração pretérita, assim como a sua manutenção enquanto perdurar a condição de dependente.

A questão da pessoa transexual ainda é muito controvertida e necessita aprofundadas reflexões diante de seus reflexos e de critérios assentados no sistema binário de gênero, sendo em todo caso indispensável que qualquer ponderação se 
dê a luz das balizas constitucionais e de seu eixo axiológico como requisito de validade, afastando qualquer compreensão discriminatória ou marginalizante.

\section{BIBLIOGRAFÍA}

- BRASIL. Constituição da República Federativa do Brasil de 05 de outubro de 1988. Disponível em: http://www. planalto.gov.br/ccivil_03/Constituicao/ Constituicao.htm. Acesso em: 23 out. 2019.

- “---.." Decreto no 678, de 06 de novembro de 1992. Disponível em: http://www.planalto. gov.br/ccivil_03/decreto/d0678.htm. Acesso em: 29 out. 2019.

- “---.." Decreto no 49.096, de 10 de outubro de 1960. Disponível em: http://www.planalto. gov.br/ccivil_03/decreto/1950-1969/ D49096.htm. Acesso em: 02 nov. 2019.

- “---.." Emenda Constitucional $n^{-}$32, de 11 de setembro de 2011. Disponível em: http://www.planalto.gov.br/ccivil_03/ constituicao/Emendas/Emc/emc32.htm. Acesso em: 29 out. 2019.

- “---." Lei complementar no 75 de 20 de maio de 1993. Disponível em: http://www. planalto.gov.br/ccivil_03/leis/lcp/lcp75. htm. Acesso em: 29 out. 2019.

- “----." Lei no 3.765, de 4 de maio de 1960. Disponível em: http://www.planalto.gov. br/ccivil_03/Leis/L3765compilado.htm. Acesso em: 29 out. 2019.

- “---.." Lei no 6.880, de 9 de dezembro de 1980. Disponível em: http://www.planalto. gov.br/ccivil_03/LEIS/16880compilada. htm. Acesso em: 29 out. 2019.

- “----." Lei no 8.625 de 12 de fevereiro de 1993. Disponível em: http://www.planalto.gov. br/ccivil_03/Leis/L8625.htm. Acesso em: 29 out. 2019

- “---.." Medida Provisória no 2.215-10, de 31 de agosto de 2001. Disponível em: http://www.planalto.gov.br/ccivil_03/ MPV/2215-10.htm\#art27. Acesso em: 29 out. 2019.
- Britto, C. A. (2003). Teoria da Constituição. São Paulo: Saraiva.

- CIDH. Corte Interamericana de Direitos Humanos. (2017). Opinião Consultiva $n^{\circ}$. 24/2017. Julgado em 24 de novembro de 2017. Disponível em: http://www.corteidh. or.cr/docs/opiniones/seriea_24_esp.pdf . Acesso em: 26 out. 2019.

- CNJ. Provimento no 73, de 28 de junho de 2018. Disponível em: https://atos.cnj.jus. br/atos/detalhar/2623. Acesso em: 03 nov. 2019.

- CNMP. Resolução no 23 de 17 de setembro de 2007. Disponível em: https:// www.cnmp.mp.br/portal/images/ Normas/Resolucoes/Resoluao_23_ alterada_143.1.pdf. Acesso em: 29 out. 2019.

- CRP. Resolução nô1, de 29 de janeiro de 2018. Disponível em: https://site.cfp. org.br/wp-content/uploads/2018/01/ Resolu\%C3\%A7\%C3\%A3o-CFP-01-2018. pdf. Acesso em: 29 out. 2019.

- Diniz, M. C. (2014). Direito a não discriminação: travestilidade $e$ transexualidade. São Paulo: Estúdio Editores.com.

- Dromi, J. R. (1997). La Reforma Constitucional: El Constitucionalismo del "por-venir". En: Enterria, Eduardo Garcia de; ARÉVALO, Manuel Clavero (coord). El Derecho Público de Finales de Siglo: Una Perpectiva Iberoamericana. Madrid: Fundación BBVA, p.107-116.

- Freitas, M. S. de; Vita, J. B. (2017) Distinção de gênero para fins de aposentação e tutela jurídica das pessoas transsexuais. Revista Novos Estudos Jurídicos, Governador Valadares, 22, (1) - 288-323. 
- Fernandes, B. G. (2018). Curso de Direito Constitucional. Salvador: JusPodivm.

- Gonçalves, C. de J. M. (2012). A transexualidade sob a ótica dos direitos humanos: uma perspectiva de inclusão. Tese de Doutorado apresentada perante a Faculdade de Direito da Universidade de São Paulo - USP, ano de 2012, p. 223. Tese integral disponível através do portal: http://www.teses.usp.br/teses/ disponiveis $/ 2 / 2140 /$ tde- 04032013 105438/pt-br.php. Acessado em: 26 out. 2019.

- Jesus, J. G. (2012). Orientações sobre a população transgênero: conceitos e termos. Brasília. Disponível em: https://issuu. com/jaquelinejesus/docs/orienta_-es_ popula_o_trans . Acesso em: 20 jan. 2019.

- Moura, R.G.; Lopes, P.L. (2014). Comportamento organizacional frente à diversidade: a inclusão de travestis e transexuais no mercado de trabalho. En: SIMPÓSIO DE EXCELÊNCIA EM GESTÃO E TECNOLOGIA, XVI, 2014, Rio de Janeiro. Anais [...]. Rio de Janeiro: Faculdades Dom Bosco, p. 01-16.

- MPF. (2017). Inquérito Civil n. 1.30.001.000522/2014-11. Disponível em: http://www.mpf.mp.br/rj/sala-deimprensa/docs/pr-rj/recomendacaotransexuais-forcas-armadas. Acesso em: 03 nov. 2019.

- OMS. (2019). International Classification of Diseases 11th Revision: The global standard for diagnostic health information. Disponível em: https://icd.who.int/ browse11/l-m/en\#/http://id.who.int/icd/ entity/90875286. Acesso em 29 out. 2019.

- Oliveira, M. T. de L. (2018). A aplicabilidade dos direitos fundamentais perante a retificação do registro civil do transexual no Brasil. Dissertação de Mestrado apresentada perante a Universidade Fundação Mineira de Educação e Cultura - FUMEC, ano de 2018, p. 128. Dissertação integral disponível através do portal: http://www.fumec.br/revistas/pdmd/ article/view/673-. Acessado em: 03 nov. 2019.

- Rezende, Renato Horta. (2017). Controle concentrado de constitucionalidade: elemento estrutural de validade das decisões sobre política pública. Curitiba: Jaruá, 2017.

- Reainaudo, Franco y Bacellar, Laura. (2008). O mercado GLS: Como Obter Sucesso Com O Segmento De Maior Potencial Da Atualidade. São Paulo: Matrix.

- Sarlet, I. W. (2018). Art. 1으, III - a dignidade da pessoa humana. En: Canotilho, J.J; Mendes, Gilmar Mendes; Sarlet, Ingo Wolfgang y STRECK, Lênio Luiz (Coord.); Comentários à Constituição do Brasil. São Paulo: Saraiva. p. 294-301.

- STF, Supremo Tribunal Federal. (2018). Ação Direta de Inconstitucionalidade $n^{\circ}$ 4275. Disponível em: http://portal. stf.jus.br/processos/downloadPeca. asp?id=15339649246\&ext=.pdf. Acesso em: 17 out. 2019.

- Travasso, G. S. (2018). A opinião consultiva $n^{\circ}$. 24/2017 da Corte Interamericana de Direitos Humanos: a identidade de gênero como núcleo componente da dignidade da pessoa humana. Revista Defensoria Pública da União, (11), 65-88.

- TRF 2a Região. (2017). Sentença em Mandado de Segurança no 0155101 65.2017.4.02.5101. Disponível em: https://dje.trf2.jus.br/DJE/Paginas/ VisualizaDocumento.aspx?ID=9971580. Acesso em 1 nov. 2019.

- Vieira, T. R. (2008). Nome e Sexo: mudanças no registro civil. São Paulo: Editora Atlas. 